\title{
Acts of Requesting as Realized by English for Specific Purposes Students
}

\author{
Arif Nugroho \\ IAIN Surakarta \\ E-Mail: arif.nugroho@iain-surakarta.ac.id
}

Nuning Wahyu Astuti

IAIN Surakarta

\section{Arief Eko Priyo Atmojo}

IAIN Surakarta

DOI: https://doi.org/10.18326/jopr.v3i1.46-58

Copyright (C) The Author (s)

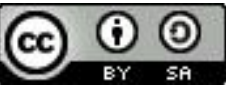

This work is licensed under a Creative Commons Attribution-ShareAlike 4.0 International License.

How to Cite: Nugroho, A., Astuti, N., \& Atmojo, A. (2021). Acts of Requesting as Realized by English for Specific Purposes Students. Journal of Pragmatics Research, 3(1). doi: https://doi.org/10.18326/jopr.v3i1.46$\underline{58}$

\section{SUBMISSION TRACK: \\ Received: 20-01-2021 \\ Final Revision: 05-03-2021 \\ Available online: \\ 01-04-2021 \\ Corresponding \\ Author: \\ Arif Nugroho arif.nugroho@iain- surakarta.ac.id}

\begin{abstract}
The success of language learners' intercultural communication highly depends on their acquisition of not only grammatical knowledge but also pragmatic aspects of the target language. However, research examining English for specific purposes (ESP) learners' request realization, as a crucial indicator of pragmatic competence, still remains a paucity of evidence. Addressing this issue, the present study aims to examine English for specific purposes (ESP) students' most frequently used request strategy and their reasons behind the selected strategy. To this end, 36 ESP students of a public university at Surakarta Indonesia were involved in a descriptive qualitative study. A set of Discourse Completion Test (DCT), role-play, and semi-structured interview were employed as a means of data collection. The data were analyzed based on Blum-Kulka and Olshtain's Cross-Cultural Study of Speech Act Realization Patterns (CCSARP) and followed by thematic content analysis for the interview responses. The results depicted that conventionally indirect request were the most frequently used strategy by the students than other strategies, i.e. direct request and non-conventionally indirect request. The semistructured interview further revealed that cultural factors, degree of politeness, and social distance among the interlocutors became the primary reasons of the students' massive selection of conventionally indirect strategy. These results offer fruitful insights for English language teaching stakeholders as an effort to equip ESP students with satisfactory pragmatic and cross-cultural knowledge.

Keywords: acts of requesting, pragmatics, request strategies,
\end{abstract}




\section{Journal of Pragmatics Research}

Vol. 03, No. 01 (2021), pp.46-58

E-ISSN: $2656-8020$

Website: http://e-journal.iainsalatiga.ac.id/index.php/jopr/index

\section{INTRODUCTION}

Successful communication in a foreign language not only depends on the acquisition of sentence structures and grammatical rules of the language but also entails the knowledge of pragmatics and cross-cultural communication. In other words, a successful language learner should master communicative competences that include the ability to understand the language discourse (grammatical competence) and to use appropriate language in a real context of communication (pragmatic competence) (Daskalovska et al., 2016; Nugroho \& Rekha, 2020). Hence, in the context of English as a foreign language such as in Indonesia, English language teaching (ELT) classroom plays a crucial role in developing students' communicative competences (Ashoorpour et al., 2014). However, for years ELT scholars (Güneş \& Ortaçtepe, 2019; $\mathrm{Hu}, 2014$; Li et al., 2015) argue that English language teaching is mostly devoted to learn grammatical rules of the language instead of language functions as a means of communication. This becomes a crucial issue since nowadays communicative competence is considered as a twenty-first century skill that should be acquired by language students (Haghighi et al., 2019). For this reason, examining EFL students' ability of language functions (e.g. pragmatic competence) becomes an interesting inquiry, particularly in the context of English for specific purposes (ESP) where the use the language in an appropriate context is highly required.

It is undeniable that the idea of pragmatic competence is derived from the concept of speech acts. As defined by Searle (1974), a speech act is an utterance that not only contains an information but also delivers a certain intention (Yule, 1996). In global interaction and communications, the utterances implying speech acts that deliver various communicative intentions often take place (Sattar et al., 2009). Moreover, utterances coming from speakers having different social and cultural backgrounds potentially result in the emergence of different communication styles that convey various meaning and intention (Krisnawati, 2011). By this context, it is clear that an English speaker has to get the hang of the knowledge of language use in addition to the grammatical competence to be able to communicate appropriately among different cultures and communication styles. This is in line with the aims of ESP teaching that is to fulfill students' needs of language knowledge and skills (mostly communication skill) to support the development of a future career based on their own fields (Nimasari, 2018). Therefore, ELT classroom should facilitate students' development of both grammatical competence and pragmatic competence.

Thuruvan and Yunus (2017) stated that all speech acts are having an intention, and catching with the intention might become a problem for some speakers. For instance, an utterance such as “do you have a pen?" is not merely asking if the interlocutor has a pen, but indicates an indirect request to borrow a pen. Understanding this kind of meaning behind an utterance is crucial in real 
context of communication; hence, investigating speech acts of requests is still becoming an interesting inquiry among the scholars (Yazdanfar \& Bonyadi, 2016). The acts of requesting has attracted researchers' intention since it is considered as a face-threatening act - an act often encountered by the interlocutors in a communication. In understanding speech acts of requests, the Cross-Cultural Speech Act Realization Pattern (CCSARP) by Blum-Kulka and Olshtain (1984) (see table 1) was often employed in some languages such as English, Hebrew, and Danish. Since then, studies examining the request strategies using the CCSARP were conducted in the context of pragmatics and cross-cultural communication (Güneş \& Ortaçtepe, 2019; Maros \& Halim, 2018; Sari et al., 2015; Yazdanfar \& Bonyadi, 2016).

Table 4.1. CCSARP Request Strategies Classification

\begin{tabular}{|c|c|c|}
\hline Request Strategies & Types & Examples \\
\hline \multirow[t]{5}{*}{ Direct } & $\begin{array}{l}\text { 1. Mood derivable: determining } \\
\text { semantic meaning of the utterance } \\
\text { (imperative). }\end{array}$ & Bring me a glass of water. \\
\hline & $\begin{array}{l}\text { 2. Explicit performatives: stating the } \\
\text { explicit illocutionary meaning of } \\
\text { the utterance. }\end{array}$ & $\begin{array}{l}\text { I'm asking you to bring a glass of } \\
\text { water. }\end{array}$ \\
\hline & $\begin{array}{l}\text { 3. Hedged performatives: the } \\
\text { illocutionary meaning is modified } \\
\text { by hedging expressions. }\end{array}$ & $\begin{array}{l}\text { I'd like to ask you to bring a glass of } \\
\text { water for me. }\end{array}$ \\
\hline & $\begin{array}{l}\text { 4. Obligation statements: stating the } \\
\text { direct illocutionary meaning with } \\
\text { obligations. }\end{array}$ & $\begin{array}{l}\text { You should bring me a glass of } \\
\text { water. }\end{array}$ \\
\hline & $\begin{array}{l}\text { 5. Want statements: expressing the } \\
\text { desire of the speakers }\end{array}$ & $\begin{array}{l}\text { I want you to bring a glass of water } \\
\text { for me. }\end{array}$ \\
\hline \multirow[t]{2}{*}{$\begin{array}{l}\text { Conventionally } \\
\text { Indirect }\end{array}$} & $\begin{array}{l}\text { 6. Suggestory formulae: containing a } \\
\text { suggestion to do. }\end{array}$ & $\begin{array}{l}\text { Why don't you bring a glass of water } \\
\text { for me? }\end{array}$ \\
\hline & $\begin{array}{l}\text { 7uery preparatory: containing } \\
\text { references to a preparatory } \\
\text { condition such as ability, } \\
\text { willingness, and permission to } \\
\text { perform an act. }\end{array}$ & $\begin{array}{l}\text { Could you bring me a glass of water? } \\
\text { Would you mind to bring me a glass } \\
\text { of water? }\end{array}$ \\
\hline \multirow[t]{2}{*}{$\begin{array}{l}\text { Non-conventionally } \\
\text { indirect }\end{array}$} & $\begin{array}{l}\text { 8. Strong hint: holding partial } \\
\text { reference of the object required to } \\
\text { implement the act. }\end{array}$ & I'm very thirsty. \\
\hline & $\begin{array}{l}\text { 9. Mild hint: no reference is } \\
\text { produced, but interpretation is } \\
\text { highly possible from the context. }\end{array}$ & $\begin{array}{l}\text { A glass of hot water seems delicious } \\
\text { in this cold weather. }\end{array}$ \\
\hline
\end{tabular}

Source: Adapted from Blum-Kulka and Olshtain (1984)

In the context of English as a foreign language in Indonesia, studies about speech acts of requests have also been conducted for years. By employing written Discourse Completion Test (DCT) with nine situations, Susilo (2015) examined how junior high school students expressed their request strategies in English. The results showed that the students employed both direct and indirect request strategies; however, conventionally indirect request was revealed as the most utilized one in the form of willingness and permission. In a similar direction, Nugroho (2019) delineated the request strategies employed by Indonesian English teachers and the reason behind the selection of such strategies. Similar to Susilo's (2015) findings, the results showed that conventionally indirect request was the most utilized strategy. The reason behind the selection was the consideration of situational variables (e.g. social distance, power, and rank of imposition) in 


\section{Journal of Pragmatics Research}

Vol. 03, No. 01 (2021), pp.46-58

E-ISSN: $2656-8020$

Website: http://e-journal.iainsalatiga.ac.id/index.php/jopr/index

the communication. More recently, Nugroho and Rekha (2020) depicted that English department students made use of similar strategy to convey speech acts of requests in English.

Given the fact that most of the above-mentioned previous studies were conducted with teachers and students coming from English department, the questions that may arise are "what about English for specific purposes students?" "Do they convey similar request strategy?" These questions come up because ESP students tend to have lower level of language awareness and it may affect the choice of request strategy in English. Having a delineation on this issue is crucial to portray a comprehensive understanding about the realization of requesting acts among English language teaching contexts. Therefore, the in-hand study is directed to examine ESP students' most frequently used request strategy based on Blum-Kulka and Olhstain's CCSARP. Moreover, their reasons behind the selection of the strategies are also revealed to have a comparison with the previous findings. What else put this study differs from the previous research is that the use of role-play as an effort to collect the participants' natural request utterances in addition to the written DCT. The results contribute as an input enhancement of literature review in the realm of pragmatics and speech acts, particularly in ESP context.

\section{RESEARCH METHOD}

A descriptive qualitative research was employed to portray how ESP students realized acts of requesting in English. The data were in the form of request utterances obtained conveniently from 36 ESP students (male $=11$; female $=25$ ) majoring in management and business at a public university in Surakarta Indonesia. They were first-year students taking English for management and business as a compulsory subject at the university. Their age was between 17 and 20 and the average was 18. This study was administered in the end of semester; thus, the participants had already finish the English lesson. All the 36 participants were asked to provide their responses on a written discourse completion test (DCT). Moreover, based on their request responses in the DCT, 25 of them were selected as participants in the role-play. Finally, 6 participants were invited in semi-structured interviews to depict their reasons behind the selection of the request strategies.

This study used discourse completion test (DCT), role-play, and semi-structured interview as research instruments to collect the data. First, the DCT consisting of 12 situations adapted from Nugroho (2019) (see table 2) was administered to elicit the request strategies as realized by the participants. Each situation contained a description for the participants completed with a blank space where they should write their request utterances as though they were the speakers in real communication as described in the situation, for instance:

Situation 1: You are doing your school project that should be submitted tomorrow. It's about 8 p.m. A new neighbor next to your boarding room is playing music loudly. He is about your age and you do not already know him. Since you are disturbed with the sounds of the music and 
cannot concentrate on your work, you want to ask him decrease the volume. How will you convey the request?

Second, out of 36, 25 participants were considered worthy to involve in the role-play. The roleplay was administered to guarantee the natural responses of request utterances produced by the participants to support the administration of DCT. Due to the time constraint, the role-play consisted of 6 scenarios adapted from Syahri and Kadarisman (2007) (see table 2) where the participants should practice conversation containing request utterances by playing the role as described in the scenario. To avoid repetition of request utterances, the participants should take a piece of paper where a scenario was written and it was rolled into coupons. They were assigned to randomly choose some coupons and perform dialogue with their group members before the other participants based on several roles described in the scenario. While listening to the participants' dialogue, the researchers took notes all request utterances that were spoken by the participants for the purpose of data analysis. An example of scenario in role-play is as follows:

Scenario 1: You are looking for references at the campus library to do a project given by your lecturer. You have some notes about books and journal articles that you are looking for but you have difficulty in finding the location. So, you want to ask a librarian whom you already know to help you. How will you convey your request? [Roles: a student and a librarian]

Third, a semi-structured interview was administered to 6 participants to reveal their actual reasons of the request strategy selection. It enables the researchers to jump into an in-depth understanding on the phenomenon being studied with a question guidance at hands, but still can go beyond to explore the participants' answers (Yin, 2015). In this stage, the interviews were conducted both in Indonesia and English, depending on the participants' preferences. The interviews last for about 15 to 20 minutes of each participant and being recorded for the sake of data transcription.

Table 4.2. Items of DCT and Role-Play

\begin{tabular}{|c|c|c|}
\hline & DCT & Role-play \\
\hline Scenario 1 & $\begin{array}{l}\text { Asking a new neighbor to turn down music } \\
\text { volume }\end{array}$ & $\begin{array}{l}\text { Asking a librarian to find the location of books } \\
\text { and other references }\end{array}$ \\
\hline Scenario 2 & $\begin{array}{l}\text { Asking a person whom do not already know to } \\
\text { borrow his pen. }\end{array}$ & Asking a fellow friend to give a ride home. \\
\hline Scenario 3 & $\begin{array}{l}\text { Asking permission to parents to join a } \\
\text { competition held by an overseas university. }\end{array}$ & $\begin{array}{l}\text { Asking a lecturer to have a consultation on the } \\
\text { final paper. }\end{array}$ \\
\hline Scenario 4 & $\begin{array}{l}\text { Asking a shop assistant to find a suitable size of } \\
\text { T-shirt. }\end{array}$ & $\begin{array}{l}\text { Asking a fellow friend to accompany watching } \\
\text { movie at a cinema. }\end{array}$ \\
\hline Scenario 5 & $\begin{array}{l}\text { Asking a student whom do not already know to } \\
\text { take a picture of the participants. }\end{array}$ & $\begin{array}{l}\text { Asking an older brother to accompany to go to } \\
\text { a grandmother's house. }\end{array}$ \\
\hline Scenario 6 & Asking a fellow classmate to borrow a textbook. & Asking a shoes keeper to find a suitable size. \\
\hline Scenario 7 & $\begin{array}{l}\text { Asking a waiter at restaurant to pass some more } \\
\text { water. }\end{array}$ & \\
\hline Scenario 8 & $\begin{array}{l}\text { Asking a direction to the participant's father } \\
\text { friend. }\end{array}$ & \\
\hline Scenario 9 & $\begin{array}{l}\text { Asking for help to a fellow friend to do a school } \\
\text { project. }\end{array}$ & \\
\hline Scenario 10 & $\begin{array}{l}\text { Asking a lecturer's permission to not to join a } \\
\text { class to attend a family wedding. }\end{array}$ & \\
\hline Scenario 11 & $\begin{array}{l}\text { Asking a direction to a younger teenager to get to } \\
\text { a place. }\end{array}$ & \\
\hline Scenario 12 & $\begin{array}{l}\text { Asking a neighbor's car to visit a cousin in a } \\
\text { hospital. }\end{array}$ & \\
\hline
\end{tabular}




\section{Journal of Pragmatics Research}

Vol. 03, No. 01 (2021), pp.46-58

E-ISSN: $2656-8020$

Website: http://e-journal.iainsalatiga.ac.id/index.php/jopr/index

Source: Adapted from Nugroho (2019) \& Syahri and Kadarisman (2007)

With regards to data analysis, the Cross-Cultural Study of Speech Acts Realization Patterns (CCSARP) by Blum-Kulka and Olshtain (1984) was used as the basis of data categorization of the responses obtained from DCT and role-play to see the request strategies conveyed by the participants. The results were tabulated by means of percentage using Ms. Excel to see the distribution of request strategies as employed by the participants across all situations and scenarios. The thematic content analysis was further applied to examine the participants' reasons in selecting their request strategies. Finally, the researchers made classification of the interview data based on the emerging themes and further used as the basis of data conclusion and interpretation.

\section{RESULTS}

This section highlights results of data analysis and the interpretation of the results with regards to two primary themes, i.e. English for specific purposes students' request strategies and reasons behind the selection of the strategies. Representative responses of the participants' are quoted to support the delineation of the findings. Several responses in Indonesian are translated without altering the meaning to ensure the language efficacy.

\section{The request strategies as realized by English for specific purposes students}

The data in the form of request utterances as realized by 36 ESP students by means of DCT were varied and comprised all request strategies, i.e. direct, conventionally indirect, and nonconventionally indirect. Nevertheless, the findings showed significant different distribution of the requests strategies (see table 3). From 432 request realizations obtained from the DCT, 12 (2.8\%) of them were classified as data biases, 8 of them were left blank and the other 4 did not reflect request utterances. Moreover, table 3 shows that conventionally indirect request $(376 ; 89.5 \%)$ in the form of query preparatory $(339 ; 80.7 \%)$ was the most-frequently used strategy employed by the ESP students to convey their speech acts of requests. The less frequently used strategy was direct request $(30 ; 7.14 \%)$ and the least frequent strategy was non-conventionally indirect request $(14 ; 3.3 \%)$.

Table 4.3. Distribution of Request Strategies in DCT

\begin{tabular}{ccc}
\hline Request Strategies & N & Percentage (\%) \\
\hline Direct & $\mathbf{3 0}$ & $\mathbf{7 . 1 4}$ \\
\hline Mood derivable & 14 & 3.3 \\
Explicit performatives & 3 & 0.7 \\
Hedged performatives & 8 & 1.9 \\
Obligation statements & 1 & 0.2 \\
Want statements & 4 & 0.9 \\
\hline Conventionally indirect & $\mathbf{3 7 6}$ & $\mathbf{8 9 . 5}$ \\
\hline Suggestory formulae & 37 & 8.8 \\
Query preparatory & 339 & 80.7 \\
\hline Non-conventionally indirect & $\mathbf{1 4}$ & $\mathbf{3 . 3}$ \\
\hline Strong hint & 4 & 0.9 \\
Mild hint & 10 & 2.4 \\
\hline
\end{tabular}




\begin{tabular}{lll}
\hline Total & 420 & 100 \\
\hline
\end{tabular}

Table 3 demonstrates that conventionally indirect becomes the most frequently used strategy to convey requesting acts among the participants in the DCT. For instance, when they were asked to deliver a request to a new neighbor who raise the volume of his music in a late night (situation 1), a participant said "Could you please lower down your music volume. I have to finish my tomorrow's school assignment". Another conventionally indirect request was provided by one of the participants in respond to the situation 3 where the participants were required to convey request for their parents to join a competition. He wrote "Pardon me mom, I'd like to join a completion but it is held in an overseas university. I need your permission. So, may I join the competition?" In short, request utterances obtained from DCT were mostly in the form of conventionally indirect request, with query preparatory as the sub-strategy.

As for the utterances obtained from role-play, 25 participants have made 72 request realizations. The results show similar trend to the findings of DCT that conventionally indirect request $(39 ; 54.1 \%)$ was the most frequently used strategy employed by the participants in roleplay, followed by direct request $(31 ; 43.2 \%)$ and non-conventionally indirect request $(2 ; 2.7 \%)$. There was an interesting finding that the participants of role-play conveyed significant increase of direct request strategy (43.2\%) as compared to the DCT responses $(7.14 \%)$. The possible reason was that Indonesian speakers of English might tend to be more direct when having a real context of conversation.

Table 4.4. Distribution of Request Strategies in Role-play

\begin{tabular}{lcc}
\hline \multicolumn{1}{c}{ Request Strategies } & N & Percentage (\%) \\
\hline Direct & $\mathbf{3 1}$ & $\mathbf{4 3 . 2}$ \\
\hline Mood derivable & 21 & 29.3 \\
Explicit performatives & 1 & 1.4 \\
Hedged performatives & 2 & 2.7 \\
Obligation statements & 7 & 9.8 \\
Want statements & - & - \\
\hline Conventionally indirect & $\mathbf{3 9}$ & $\mathbf{5 4 . 1}$ \\
\hline Suggestory formulae & 12 & 16.6 \\
Query preparatory & 27 & 37.5 \\
\hline Non-conventionally indirect & $\mathbf{2}$ & $\mathbf{2 . 7}$ \\
\hline Strong hint & 2 & 2.7 \\
Mild hint & - & - \\
\hline Total & $\mathbf{7 2}$ & $\mathbf{1 0 0}$ \\
\hline
\end{tabular}

Table 4 presents the participants' request realizations obtained from the Role-play. The conventionally indirect request still became the most frequently used strategy by the participants to deliver requests; however, the number significantly decreased compared to the DCT responses. The direct strategy in the form of mood derivable became another alternative for the participants in the Role-play to express their requests. For instance, in respond to the situation 1 where they were asked to make a request for a librarian to find the location of a book, one of them said "Show 


\section{Journal of Pragmatics Research}

Vol. 03, No. 01 (2021), pp.46-58

E-ISSN: $2656-8020$

Website: http://e-journal.iainsalatiga.ac.id/index.php/jopr/index

me the location of this book, please". Another example was a response to the situation 5 in which the participants were to convey request for a shoe keeper to find a suitable size for them, one of them said "Find me a suitable size for this shoes, please". Briefly, the responses of Role-play shows a surprising result where the number of direct request was significantly increased than the results of DCT.

\section{The reasons of English for specific purposes students in employing the request strategies}

The results of data analysis from DCT and role-pay obviously show that conventionally indirect request was the most frequently utilized strategy by ESP students in conveying requests in English. For this reason, this study was directed to further examine the participants' intention behind the massive selection of this strategy. Moreover, the significant increase of direct requests in the role-play also attracted the researchers' attention; therefore, the semi-structured interviews involved representative participants who conveyed direct strategy in the role-play to scrutinize this interesting issue. The results of semi-structured interviews with 6 participants reveal the answer of this inquiry.

Based on the interview responses, there were two main reasons of the participants' massive selection of conventionally indirect strategy. First, cultural background seemed to be a significant reason of the participants' selection of conventionally indirect request strategy. The participants stated that they chose conventionally indirect because it was appropriate with the eastern cultural where Indonesia as a place they lived belonged to. Moreover, they looked at conventionally indirect strategy as a request they commonly encountered in the context of English as a foreign language communication in Indonesia at any situation without considering the social status of the interlocutors. They deemed this strategy as the most proper utterances to convey a request across all situations and communication context. As an interview participant said:

"Ok right. My main reason to use this kind of strategy [conventionally indirect] when I give a request is due to our eastern culture teaches us to do so. Hmm... as far as I know from my English teachers and reading some books, when we give a request in English we commonly use "could" or "would" and added with the word "please". I think that it sounds good and is suitable with our Indonesian culture. So, I choose to use this strategy to express my requests". (Int. P2)

Second, the participants' selection of conventionally indirect request was significantly affected by the politeness degree. It was clearly related to the cultural factor that they were bounded of the eastern culture where being a polite person is necessary in communicating with anyone, any place, and in any circumstance. The results of semi-structured interviews revealed that the participants tended to be considered as a kind person by speaking politely, including in delivering requesting acts. They also confessed that using conventional indirect request made them comfortable to the interlocutors. As an interview participant said: 
"........ and my only intention choosing conventionally indirect strategy is that I want to be seen as a polite person. In my opinion, this model of request is the most polite among other strategies. Besides, I feel comfortable to use the word "could" and "would" to deliver my request to other people, whoever the person I speak with and in any place." (Int. P5)

In addition, the significant increase of direct request strategy in role-play compared to the participants' responses in DCT has attracted the researchers' interest. With regard to this, the interview responses showed that the variable of social distance highly contributed to the participants' selection of direct request in role-play. The participants stated that when having a real communication, they would consider the shortest and easiest strategy to convey requests. They also considered a more direct request when asking a favor to their fellow and close friends, while they would come to a more indirect when requesting a person with higher social status such as parents, teachers, and elder brothers. However, this fact did not apply when they were conveying requests through DCT. It becomes an interesting finding. As an interview participant said:

"I prefer to use direct request like the sentence "open the door please" when asking my close friends or my little brother. But I will say "Could you please open the door" if I talk to my elder brother. This because I feel more respect to my elder brother so I must use more polite words to talk to him." (Int. P1)

"Yes, I don't know why I spontaneously use direct request when practicing dialogue and the role I said request to my friends. But I think direct request is more simple, short, and easy to practice. Of course if I speak to people who are older than me or having higher social status I prefer to choose indirect strategy and use the words "could" and "please". (P.6)

\section{DISCUSSION}

The data analysis reveals several compelling results related to the two main themes associated to the present study. With regards to request strategies as realized by English for specific purposes students, this study's result depicts that conventionally indirect with querypreparatory is the most massively used strategy to convey request utterances. However, an interesting finding is revealed that the number of direct request significantly increases when the participants delivering requests through role-play. Furthermore, the results of semi-structured interviews indicate that cultural background, degree of politeness, and variable of social distance are proven to be several factors affecting the participants' selection of request strategy.

So, what do the findings imply for us? The massive use of conventionally indirect request indicates that Indonesian English for specific purposes students were lack of pragma-linguistic diversity when conveying speech acts of requests. This result accords with the finding reported by Nugroho and Rekha (2020) that Indonesian speakers of English are often trapped in the overuse of auxiliaries "can", "could", and "would" when performing acts of requesting. The use of such auxiliaries undeniably provides the speakers an opportunity to have a high level of politeness (Jeanyfer \& Tanto, 2018; Krisnawati, 2011; Thuruvan \& Yunus, 2017). However, the results of Güneş and Ortaçtepe's (2019) inquiry reported that native English speakers conveyed a variety of 


\section{Journal of Pragmatics Research}

Vol. 03, No. 01 (2021), pp.46-58

E-ISSN: $2656-8020$

Website: http://e-journal.iainsalatiga.ac.id/index.php/jopr/index

similar expressions to produce requests such as "Would you mind to .......?", Would it be possible to ...?", and "Do you think it will be possible to......?". When it comes to this study's results, we can conclude that Indonesian ESP students failed to jump into that variety of request expressions. The possible reason for this failure might be due to Indonesian ELT context often emphasizes the use of modals "can" and "could" in the classroom both by teachers and students when performing requests. Moreover, overemphasis on grammatical rules rather than on pragmatic aspect of the language might lead Indonesian speakers of English possess limited knowledge of request expressions other than using "can" and "could".

It was further portrayed that the participants' selection of request strategy was greatly affected by culture, politeness, and social status among the interlocutors. This finding provides empirical enhancement to the results of Nugroho (2019) that depicted the involvement of situational variables (e.g. social distance, power, and rank of imposition) as factors influencing the selection of request strategy. It is a common sense that speakers of an international language will brings their cultural identity when interacting with other speakers having different cultural backgrounds (He, 2019). This study proves that a common proverb "learning a language is also learning its culture" is contextually true as to achieve a successful communication requires not only the knowledge of grammar but also the ability to use the language in an appropriate communication context. Hence, this study suggests that Indonesian learners of English should be equipped with pragmatic competence and cultural awareness to enhance their cross-cultural communicative competence.

This study's results provide several implications for English language teaching. Scholars (Muthusamy \& Farashaiyan, 2016; Thuruvan \& Yunus, 2017; Yazdanfar \& Bonyadi, 2016) have come up with a conclusion that pragmatic knowledge is teachable. He (2019) stated that pragmatic competence is developed by a comprehensive acquisition and education process. Thus, Indonesian ELT context is strongly encouraged to foster students' pragmatic and cultural awareness by designing appropriate teaching activities and trainings. Also, the results may remarkably contribute to Indonesian speakers of English as fruitful insights to avoid communication breakdown by having familiarity with various strategies to convey acts of requesting. Last but not least, researchers whose specialization concerns on speech acts and pragmatic competence may take benefits from this study's results to conduct similar context of inquiry.

\section{CONCLUSION}

As a conclusion, this study results in an empirical finding that English for specific purposes students convey conventionally indirect as the most frequently used strategy to deliver acts of requesting. Another finding depicts that culture, politeness degree, and social distance greatly influence the students' selection of request strategies. These findings provide practical 
contribution for developing ESP learners' pragmatic awareness and cross-cultural competence. The authors expect that the results of this study will also have multiple advantages for ELT stakeholders and future researchers who share similar issues. Notwithstanding the facts, since this study takes a focus on the contextualization of the phenomena being studied, the findings on ESP learners' request strategy may not represent the population of Indonesian EFL learners in general. Therefore, the authors suggest that further research in similar inquiries should be conducted by inviting greater number of participants who share different cultural and education backgrounds as a consistent effort to examine the English learners' pragmatic and cross-cultural communicative competence. Another suggestion for future research is to examine other potential factors that may influence the selection of language learners' selection of request strategies such as family background, socio-economic background, level of English proficiency, etc.

\section{REFERENCES}

Ashoorpour, B., Azari, H., \& Branch, T. (2014). The Relationship Between Grammatical Knowledge and Pragmatic Knowledge of Speech Act of Request in Iranian EFL Learners. 3(February), 39-47.

Blum-kulka, S., \& Olshtain, E. (1984). Requests and apologies: A cross-cultural study of speech act realization patterns (CCSARP). Applied Linguistics, 5(3), 196-213. https://doi.org/10.1093/applin/5.3.196

Daskalovska, N., Ivanovska, B., Kusevska, M., \& Ulanska, T. (2016). The Use of Request Strategies by EFL Learners. Proceeding of the International Conference on Teaching and Learning English as an Additional Language, Antalya, Turkey. https://doi.org/10.1016/j.sbspro.2016.10.015.

Güneş, Ç., \& Ortaçtepe, D. (2019). Conceptual Socialization in EFL Contexts: A Case Study on Turkish EFL Learners' Request Speech Acts Realization. Dil ve Dilbilimi Çalışmaları Dergisi, 15(1), 376-399. https://doi.org/10.17263/jlls.547766

Haghighi, H., Jafarigohar, M., Khoshsima, H., \& Vahdany, F. (2019). Impact of flipped classroom on EFL learners' appropriate use of refusal: achievement, participation, perception. Computer Assisted Language Learning, 32(3), 261-293. https://doi.org/10.1080/09588221.2018.1504083

He, B. (2019). Culture and Pragmatic Competence Development. Advances in Social Science, Education and Humanities Research, Volume 319 (ICHSSR). https://doi.org/10.2991/ichssr-19.2019.46.

$\mathrm{Hu}$, Z. (2014). Study on developing chinese college EFL learners' pragmatic competence in relation to language proficiency and overseas experience. Journal of Language Teaching 


\section{Journal of Pragmatics Research}

Vol. 03, No. 01 (2021), pp.46-58

E-ISSN: $2656-8020$

Website: http://e-journal.iainsalatiga.ac.id/index.php/jopr/index

and Research, 5(2), 391-398. https://doi.org/10.4304/jltr.5.2.391-398

Jeanyfer., \& Tanto, T. (2018). Request Strategies in Indonesian: an Analysis of Politeness

Phenomena in Text Messages. Journal of Language and Literature, 18(2), 132-137. https://doi.org/10.24071/joll.2018.180204

Krisnawati, E. (2011). Pragmatic competence in the spoken english classroom. Indonesian Journal of Applied Linguistics, 1(1), 105-115. https://doi.org/10.17509/ijal.v1i1.102

Li, R., Suleiman, R. R. R., \& Sazalie, A. (2015). An investigation into Chinese EFL learners' pragmatic competence. GEMA Online Journal of Language Studies, 15(2), 101-118. https://doi.org/10.17576/gema-2015-1502-07

Maros, M., \& Halim, N. S. (2018). Alerters in Malay and english speech act of request: A contrastive pragmatics analysis. 3L: Language, Linguistics, Literature, 24(1), 69-83. https://doi.org/10.17576/3L-2018-2401-06

Muthusamy, P., \& Farashaiyan, A. (2016). Situational Variations in Request and Apology Realization Strategies among International Postgraduate Students at Malaysian Universities. English Language Teaching, 9(3), 181. https://doi.org/10.5539/elt.v9n3p181

Nimasari, E. P. (2018). An ESP Needs Analysis: Addressing the Needs of English for Informatics Engineering. JEES (Journal of English Educators Society), 3(1), 23. https://doi.org/10.21070/jees.v3i1.1085

Nugroho, A. (2019). Request Realizations of Indonesian Esp Lecturers. A Journal of Culture English Language Teaching Literature \& Linguistics, 6(1), 1. https://doi.org/10.22219/celticumm.vol6.no1.1-13

Nugroho, A., \& Rekha, A. (2020). Speech Acts of Requests: A Case of Indonesian EFL Learners. Journal of English Language Teaching and Linguistics, 5(1), 1-16.

Sari, R. P., Raja, P., \& Sudirman, S. (2015). Politeness and Request Strategies in Act of Request By Efl Students. UNILA Journal of English Teaching, 4(7).

Sattar, H. Q., Lah, S. C., \& Suleiman, R. R. R. (2009). Iraqi postgraduates' production and perception of requests: A pilot study. International Journal of Language, Society and Culture, 29(29), 56-70. https://doi.org/10.1111/j.1532-950X.2012.01065.x

Searle, J. 1974. Speech Acts: An essay in the philosophy of language. Cambridge: Cambridge University Press.

Susilo, W. H. (2015). Requests in EFL : Interlanguage pragmatic study on Indonesian learners of English. Kajian Linguistik dan Sastra, 27(2), 77-88. 
Syahri, I., \& Kadarisman, A. E. (2007). Pragmatic Transfer in Request Realizations. TEFLIN Journal, 123-147. https://doi.org/10.15639/teflinjournal.v18i2/123-147

Thuruvan, P., \& Yunus, M. M. (2017). The speech act of request in the ESL classroom. $3 L$ : Language, Linguistics, Literature, 23(4), 212-221. https://doi.org/10.17576/3L-2017-230416

Yazdanfar, S., \& Bonyadi, A. (2016). Request Strategies in Everyday Interactions of Persian and English Speakers. SAGE Open, 6(4). https://doi.org/10.1177/2158244016679473

Yin, R. K. (2015). Qualitative research from start to finish. Guilford publications.

Yule, G. (1996). Pragmatics. New York: Oxford University Press. 